\title{
ANALYSIS ON POLITICAL SPEECH OF SUSILO BAMBANG YUDHOYONO: COMMON SENSE ASSUMPTION AND IDEOLOGY
}

\author{
Sayit Abdul Karim \\ University of Technology Yogyakarta \\ sayit.a.k@uty.ac.id
}

\begin{abstract}
Abstrak
Makalah ini menyajikan analisis teks pidato politik Susilo Bambang Yudhoyono (SBY), mantan presiden Indonesia pada konferensi Indonesia "Bergerak menuju keberlanjutan: bersama-sama kita harus menciptakan masa depan yang kita inginkan". Ideologi berkaitan erat dengan kekuasaan dan bahasa, karena penggunaan bahasa adalah bentuk paling umum dari perilaku sosial, dan bentuk perilaku sosial di mana kita bergantung pada asumsi yang paling 'masuk akal'. Tujuan dari penelitian ini adalah untuk membahas asumsi umum dan ideologi penggunaan bahasa dalam pidato politik SBY yang terutama didasarkan pada teori Norman Fairclough tentang bahasa dan kekuasaan dalam analisis wacana kritis. Ada dua masalah utama analisis, yaitu; pertama, apa asumsi umum dan ideologi dalam pidato politik Susilo Bambang Yudhoyono; dan kedua, bagaimana mereka berhubungan satu sama lain dalam wacana politik? Data yang digunakan dalam penelitian ini adalah dalam bentuk teks tertulis. Analisis deskriptif kualitatif digunakan untuk menganalisis asumsi umum dan ideologi dalam teks tertulis dari pidato politik Susilo Bambang Yudhoyono yang disampaikan di Riocto Entro Convention Center, Rio de Janeiro pada tanggal 20 Juni 2012. Salah satu dimensi 'akal sehat' adalah arti kata-kata. Hasil penelitian menunjukkan bahwa asumsi umum akal dan ideologi disampaikan melalui kata-kata tertentu SBY atau ekspresi secara signifikan dapat menjelaskan bagaimana politik wacana dibangun dan dipengaruhi oleh aturan SBY dan posisi, pengalaman hidup, dan hubungan kekuasaan. Dia menggunakan bahasa sebagai alat sosial yang kuat untuk menyajikan asumsi akal sehatnya dan ideologi untuk meyakinkan penonton dan sesama warga bahwa masa depan keberlanjutan telah menjadi agenda penting bagi semua orang.
\end{abstract}

Kata Kunci: Pidato Politik, akal sehat, asumsi, ideologi, keberlanjutan, pertumbuhan.

\begin{abstract}
This paper presents an analysis on political speech of Susilo Bambang Yudhoyono (SBY), the former president of Indonesia at the Indonesian conference on "Moving towards sustainability: together we must create the future we want". Ideologies are closely linked to power and language because using language is the commonest form of social behavior, and the form of social behavior where we rely most on 'common-sense' assumptions. The objectives of this study are to discuss the common sense assumption and ideology by means of language use in SBY's political speech which is mainly grounded in Norman Fairclough's theory of language and power in critical discourse analysis. There are two main problems of analysis, namely; first, what are the common sense assumption and ideology in Susilo Bambang Yudhoyono's political speech; and second, how do they relate to each other in the political discourse? The data used in this study was in the form of written text on "moving towards sustainability: together we must create the future we want". A qualitative descriptive analysis was employed to analyze the common sense assumption and ideology in the written text of Susilo Bambang Yudhoyono's political speech which was delivered at Riocto entro Convention Center, Rio de Janeiro on June 20, 2012. One dimension of 'common sense' is the meaning of words. The results showed that the common sense assumption and ideology conveyed through SBY's specific words or expressions can significantly explain how political discourse is constructed and affected by
\end{abstract}


the SBY's rule and position, life experience, and power relations. He used language as a powerful social tool to present his common sense assumption and ideology to convince his audiences and fellow citizens that the future of sustainability has been an important agenda for all people.

Keywords: Political speech, common sense, assumption, ideology, sustainability, growth. .

\section{INTRODUCTION}

None can deny that language plays an important role in all aspects of human life. Language is used to communicate, strengthen and fasten relationship among all countries in the world in all fields, including the environment, politic, business, science, technology, and many more. Studying a speech in any situation with all its functions and variation are necessarily to be conducted. It is possible to learn more about how perceptions, convictions and identities of a person's common sense assumption and ideology by means of the language used in his/her speech. Speech means communication or expression of thought in spoken words (Crystal 1980:327). It is a general word for a discourse delivered to the audience.

Through speech, speaker conveys a message to the audience either it is to convey information or insight, to persuade or to motivate. A speaker must engage his or her audience with a central idea or propositions. If a speaker does not have a clear reason to give a speech, the speech should not be given. Discourse is a stretch of language larger than a sentence (Crystal 1980:115). It is natural spoken or written language, with meaning being transferred through a sentence of a text, in context. Discourse analysis is concerned with the study of the relationship between language and the context in which it is used (McCarthy 1991:5). Some words and expression are used to show discourse is constructed. They can show the connection between what has already been written or said and what is going to be written or said. They can indicate what speakers think, feel and believe about what they are saying. In political speeches ideas and ideologies need to be expressed through a language so that they are agreed upon the receivers as well as by others who may read or hear parts of speech afterwards in media.

A political speech is not necessarily a success because of correctness or truth; rather it might be presenting valid arguments (Beard, 2000: 18). This paper examines Susilo Bambang Yudhoyono's speech addressed the honor to the audiences and participants of the Indonesian conference on "moving towards sustainability: together we must create the future we want". The present study attempts to find out the common sense assumption and ideology in written text of Susilo Bambang Yudhoyono's political speech which was delivered at Riocto entro Convention Cen- 
ter, Rio de Janeiro on June 20, 2012.

\section{Problems of the Study}

The issues stated above leads the writer to formulate two main problems of analysis, namely; first, what are the common sense assumption and ideology in Susilo Bambang Yudhoyono's political speech? and second, how do they relate to each other in political discourse?

\section{Scope of the Study}

In this study, the writer focuses himself to analyze Susilo Bambang Yudhoyono's speech in the form of written text which was delivered at the Indonesian conference at Riocto entro Convention Center, Rio de Janeiro on June 20, 2012 on "moving towards sustainability: together we must create the future we want" from the view of common sense assumption and ideology in critical discourse analysis frame work. The written text of Susilo Bambang Yudhoyono's political speech in this study was taken from the official state web site address of the following; http://www.presidensby.info/index.php/ pidato/2012/06/20/1881.html.

For the details of SBY's speech please refers to appendix 1.

\section{REVIEW OF RELATED LITERA-}

\section{TURE}

Language has become perhaps the primary medium of social control and pow- er. It has grown dramatically in terms of the use it is required to serve that is expected of the modern citizen. A crucial point is that it is possible, as we shall see, to find assumptions of the sort embedded in the form of language that is used. Such assumptions are ideologies. Ideologies are closely linked to power, because the nature of the ideological assumptions is embedded in particular conventions, and so the nature of those conventions themselves depends on the power relations which underlie the conventions.

Discourse is a broad term with various definitions which integrates a whole palette of meanings, covering a large area from linguistics, through sociology, philosophy and other disciplines (Titscher et al, 2000: 42). According to Fairclough, the term refers to the whole process of social interaction of which a text is just a part (Fairclough, 1989: 24) as pervasive ways of experiencing the world; discourses refer to expressing oneself using words. Discourses can be used for asserting power and knowledge, and for resistance and critique. The speaker expresses his/her ideological content in texts as does the linguistic form of the text. That is, selection or choice of a linguistic form may not be a live process for the individual speaker, but the discourse will be a reproduction of that previously learned discourse. Texts are se- 
lected and organized syntactic forms whose "content-structure" reflect the ideological organization of a particular area of social life (Dellinger, 1995).

Ideology is most effective when its workings are least visible. If one becomes aware of that a particular aspect of common sense is sustaining power inequalities at one's own expense, it ceases to be common sense and may cease to have the capacity to sustain power in equalities. Visibility is achieved when ideologies are brought to discourse not as explicit elements of the text, but the background assumptions which on the one hand lead the text producer to 'textualize' the word in a particular way, and on the other hand lead the interpreter to interpret the text in particular way (Fairclough, 1989: 85).

Ideologies are closely linked to language, because using language is the commonest form of social behavior, and the form of social behavior where we rely most on 'common sense' assumptions (Fairclough, 1989: 2). Language is therefore important enough to merit the attention of all citizens. Nobody who has an interest in modern society and interest in relationships of power in modern society can afford to ignore language. Fairclough argues that ideology is pervasively present in language that fact ought to mean that the ideological nature of language should be one of the major themes of modern social science (Fairclough, 1989: 3).

Ideology helps people to see the extent to which their language does rest upon common sense assumptions and the ways in which these common sense assumptions can be ideologically shaped by relation of power. Among the various forms which social struggle may take, its ideological struggle that is of particular concern in the present context because ideological struggle pre-eminently takes place in language. Ideology certainly does not give the impression of having a single fixed meaning but it has many meanings.

It is a common knowledge that politics is concerned with power: the power to make decisions, to control resources, to control other people's behavior and often to control their values. According to Jones and Peccei (2004), politicians throughout ages have achieved success thanks to their "skilful use of rhetoric", by which they aim to persuade their audience of the validity of their views, delicate and careful use of elegant and persuasive language. Rhetoric is "the art of using language so as to persuade or influence others; the body of rules to be observed by a speaker or writer in order that he may express himself with eloquence" (Oxford English Dictionary).

Thomas Jefferson and other founders of the American Republic, considered po- 
litical discourse to be the heart of democracy. Jefferson believed that instead of the social rank within which a person was born, the basis of influence within society should be discourse in a free and open discussion characterized by conflict among ideas and opinions. He noted, "Differences of opinion lead to inquiry, and inquiry to truth.” According to Webster's dictionary, the concept of discourse has two major meanings: (a) formal communication of thoughts about a serious subject through words (spoken or written) and (b) rationality or the ability to reason. Political discourse is the formal exchange of reasoned views as to which of several alternative courses of action should be taken to solve a societal problem. It is intended to involve all citizens in the making of the decision, persuade others (through valid information and logic), and clarify what course of action would be most effective in solving the societal problem.

Political discourse is a method of decision making in a democracy. A decision implies that some agreement prevails as to which of several courses of action are most desirable for achieving a goal (Johnson \& F. Johnson, 2000). Making a decision is just one step in the more general problemsolving process of goal-directed groups. After defining a problem or issue, thinking over alternative courses of action, and weighing the advantages and disadvantages of each, a decision is made as to which course is the most desirable for them to implement. According to Van Dijk (1991, 1998a), the social representations (knowledge, attitudes) shared by a group may be organized by underlying ideologies. Ideologies are by definition general and abstract, because they must apply to many different attitudes in different social domains.

The main purpose of politicians to give speech is to persuade their audience of the validity of their political will. Political influence flows from the employment of resources that shape the beliefs and behaviors of others. Common resources include expert skills, the restriction of information, the ability to confer favors on others or to injure them without physical force, and subtle or crude bribery. Edelman (1977) states that the knowledgeable politician becomes successful by "using his or her knowledge of informal influence" (Edelman, 1977, p.123).

\section{Method of Analysis}

The data used in this study was in the form of written text on "moving towards sustainability: together we must create the future we want". A qualitative descriptive analysis was employed to analyze the common sense assumption and ideology in the 
written text of Susilo Bambang Yudhoyono's political speech which was delivered at Riocto entro Convention Center, Rio de Janeiro on June 20, 2012.

\section{Significance of Study}

The findings of the analysis on the written text of President of Susilo Bambang Yudhoyono's speech will be beneficial to the readers and researchers who are interested in political discourse and as further researchers' references on critical discourse analysis (CDA), especially about common sense assumption and ideology.

\section{DISCUSSION}

Political discourse is the formal exchange of reasoned views as to which of several alternative courses of action should be taken to solve a societal problem. It is intended to involve all citizens in the making of the decision, persuade others (through valid information and logic), and clarify what course of action would be most effective in solving the societal problem. Given the power of the written and spoken discourse, Critical Discourse Analysis (CDA- henceforth) can be used for describing, interpreting, analyzing, and critiquing social life reflected in text. CDA aims to systematically explore relationships between discursive practices, texts, and events and wider social and cultural struc- tures, relations, and processes.

Looking ahead of Susilo Bambang Yudhoyono's speech at the Indonesian conference on "moving towards sustainability: together we must create the future we want" we can say that he used more scientific prediction, because the speech is delivered in a formal occasion and attended by prominent delegates who have higher social status. Thus, he used more scientific words as he assumed that the audiences understand what is considered to be conveyed by his speech.

If we look at the SBY's speech text, we can identify several words in quotation marks, showing 'common sense' as his assumptions to raise people's selfconsciousness on particular subjects. The common sense assumptions for instance, as stated by SBY in his speech: To begin with, despite the considerable expansion of the world economy, we still have not reached a world economy that is "strong, balance, sustainable". SBY in this case expressed his assumption that the economic growth which is expected by all people has yet reached, despite the considerable expansion of the world economy. In other parts of his speech, he stated that "In Indonesia, we have actively pursued a policy of "growth with equity". We have had some success. But we are also mindful that the central challenge is how to combine 
"sustainable growth" with "equity". Growth for the sake of growth in the long run will not be tenable. Hence, a policy of "sustainable growth with equity". In these parts, SBY has repeated the words "growth with equity" to show his strong assumptions that the policy made by the authority should be directed to the development of economy with equity shared for all citizens.

To secure the future climate, SBY in his speech emphasizes the important of all citizens' participation. In his common sense, both developed and developing countries should take a lead, especially for the developing countries must put more efforts. Again, he stated that To secure our climate, it is also important for us to press on with "common but differentiated responsibility and respective capability". Here, I believe that developed countries must take lead, but developing countries must do more. SBY expressed his beliefs here as his ideology on issue of the environmental climate changing in today's world. Protecting a save environment becomes convention among the people and none can deny his assumption. As we know that SBY in this forum has a big power, he used his power as the president of Indonesia to influence the audiences on the importance of the issues delivered at the conference.

Assumptions are ideologies and it is closely linked to power because the nature of the ideological assumptions embedded in particular conventions and it depends on the power relations which underlie the conventions. Ideologies are closely linked to language because using language is the commonest form of social behavior and the form of social behavior where we rely most on 'common sense' assumptions.

To show his strong believe and assumption on the importance of being together in solving the economy and environmental problem, he conveyed them through language as medium of communication in which can raise people awareness, for instance to keep global warning below the 2 Celsius degree, and people's participation, SBY express his believe through an expression There is no breakthrough without thinking outside of the box. It is clearly seen that he is trying to convince other people about the impact of the climate changes. The meaning of the expression is very deep and might influence other people's ideology as well as raise their consciousness. He is confident about what he has delivered is understood by the audiences as they are from higher education background.

SBY has tried to offer some important political decisions to be taken for all the people in order to have a sustainability of development in economy and envi- 
ronment through his state speech at the conference. Thus, his speech is also considered as political discourse. Political discourse is a method of decision making in a democracy. A decision implies that some agreement prevails as to which of several courses of action is most desirable for achieving a goal (Johnson \& F. Johnson, 2000). Making a decision is just one step in the more general problem-solving process of goal-directed groups. After defining a problem or issue, thinking over alternative courses of action, and weighing the advantages and disadvantages of each, a decision is made as to which course is the most desirable for them to implement.

In his speech, SBY state that the reasons and rationales of sustainability have become much more pressing agenda. As we can see in his speech text Population growth, the rapid rise of the middle class worldwide, the spread of mega cities, ambitious development needs-all this are adding pressures for finite resources. More people want more in a world where less is available. If we do not succeed in ensuring a sustainable future, we will inevitably live in a world of utter chaos and desperation. In this part, SBY is afraid of uncertain future situation that might be caused by the unbalance, inequity of worldwide economic growing and environmental changing. It is reasonable that SBY feels that way as the valid data shows that the climate change in the past 2 decades has worsened-with the earth getting warmer.

The main purpose of politicians to give speech is to persuade their audience of the validity of their political will. Political influence flows from the employment of resources that shape the beliefs and behaviors of others. SBY in his speech is very optimistic of the future of sustainability. $\mathrm{He}$ tried to convince people about sustainability by providing the fact as a valid argumentation (refers to the experience of Rio de Janeiro 2 decades ago), as seen in his speech: I believe the key is: technology and innovation. Just think of it. When Rio convened 2 decades ago, we did not have the internet as we now know it. We did not have cell phone, social media, nanotechnology, GPS, tablet computers. Yet, these are the things that are changing our society today, and driving the new economy. I believe that we are only seeing the tip of the iceberg, and we are certain to see more innovations flooding our society. We will see hybrid cars, energy efficient lighting; clean coal technology; solar panels; and even though they may be costly for now, the price is certain to go down just as we have seen with cell phones.

SBY might succeed to persuade the audiences through his political discourse. He emphasizes his concept of 
"sustainability growth with equity" at the conference will bring people together to solve the problems. As concluding remarks, SBY stated that no amount of international treaties and government policies and economic achievements will make a dent on sustainability unless individuals, families and societies are willing to change our lifestyle. He has also raised people's consciousness by saying in some ways; we have been victims of our own success.

His speech was ended up by expressing his big expectation on the sustainability: $W e$ need to move from "greed" economy to green economy. This is something that needs to be nurtured in our homes, in our schools, and in our workplace. If only citizens of the world pledge themselves to such a lifestyle, then sustainability will no longer be a vision but a reality. To present his common sense assumptions and ideologies he used language as a powerful social tool. The common sense assumptions, ideologies are clearly seen from SBY's specific words or expressions in the text and they can significantly explain how political discourse is constructed and affected by the SBY's rule and position, life experience, and power relations.

\section{CONCLUSIONS}

The ideology helps people to see the extent to which their language does rest upon common-sense assumptions, and the ways in which this common-sense can be ideologically shaped by relations of power. A speaker must engage his/her audience with a central idea or propositions in order to convey his/her message to the audiences or listeners in the efforts of conveying information or insight, persuading or motivating others. The common sense assumption and ideology conveyed through SBY's specific words or expressions might significantly explain how political discourse is constructed and affected by the SBY's rule and position, life experience, and power relations. He used language as a powerful social tool to present his ideology, and common sense assumption to convince his audiences and fellow citizens that the future of sustainability has been an important agenda for all people. Political discourse is the formal exchange of reasoned views as to which of several alternative courses of action should be taken to solve a societal problem. It is intended to involve all citizens in the making of the decision, persuade others (through valid information and logic), and clarify what course of action would be most effective in solving the societal problem.

\section{ACKNOWLEDGMENT}


The author would like to thank Reviewer

for the input that has been given to the im-

provement of substance to this article.

\section{BIBLIOGRAPHY}

Bayram, F. (2010). Ideology and Political Discourse: A Critical Discourse Analysis of

Erdogan's Political Speech. ARECLS, Vol. 7. 23-40. Accessed on 23 June 2012.

Dellinger, B. (1995) Critical Discourse Analysis, Available at http://users.utu.fi/ bredelli/cda.html (Accessed: 5 September 2010).

Edelman, M. J. (1977) Political language: words that succeed and policies that fail.

New York: Academic Press.

Fairclough, N. (1989) Language and Power, London: Longman Group UK Limited.

Jones, J. and Peccei, J. S. (2004) 'Language and politics', in Thomas, L.(ed), Language,

Routledge. society, and power.New York:

Martin, JR, \& Rose, D. (2003). Working with Discourse: Meaning beyond the Clause. New York: Continuum.

Titscher, S.; Meyer, M.; Wodak, R.; \& Vetter, E. (2000) Methods of text and discourse analysis. London: Sage.

Van Dijk, T. A. (2006) 'Politics, ideology, and discourse', in Brown, K.(ed), The

Encyclopedia of language and linguistics. Vol. 9 Oxford ; New York:Pergamon Press, pp. 728740. 